\title{
Effect of Hypercapnic Acidosis on Renal Function in the Newborn Rabbit ${ }^{1}$
}

\author{
A. J. v. D. HEIJDEN ${ }^{2}$ AND J. P. GUIGNARD \\ Service de Pédiatrie, Centre Hospitalier Universitaire Vaudois, Lausanne, Switzerland
}

\begin{abstract}
Anaesthetized mechanically ventilated newborn rabbits were exposed to different degrees of hypercapnia. One hour of normocapnia was used as a control period. Renal function studies demonstrated an increase in renal vascular resistance with a concomitant decrease in effective renal plasma flow in all hypercapnic animals, combined with a less pronounced decrease in glomerular filtration rate. Filtration fraction rose significantly. A decrease in systemic blood pressure was only observed when the $\mathrm{P}_{\mathrm{a}} \mathrm{CO}_{2}$ exceeded $100 \mathrm{~mm} \mathrm{Hg}$ combined with an arterial pH below or equal to 7.10 . We conclude that normoxemic hypercapnia in the newborn rabbit leads to an increase in renal vascular resistance and suggest that the renal vasoconstriction predominates at the level of the efferent arteriole. (Pediatr Res 20: 798-801, 1986)
\end{abstract}

\section{Abbreviations}

GFR, glomerular filtration rate

RBF, renal blood flow

RVR, renal vascular resistance

$\mathrm{E}_{\mathrm{PAH}}$, extraction of paraaminohippurate

$\mathrm{C}_{\mathrm{PAH}}$, clearance of PAH

MAP, mean arterial pressure

AVP, arginine vasopressin

A decrease in GFR and urine output has been described in newborn infants presenting with severe respiratory distress syndrome (1-3). The factors responsible for these disturbances include hypoxemia, hypercapnia, acidosis, and a fall in systemic blood pressure. The effect of isolated acute hypercapnic acidosis has not been extensively studied in animals whose nephrogenesis has not yet been completed. Rosenberg et al. (4) observed a consistent but not significant decrease in RBF in lambs undergoing mild hypercapnia $\left(\mathrm{P}_{\mathrm{a}} \mathrm{CO}_{2} 60-70 \mathrm{~mm} \mathrm{Hg}\right)$. In contrast, no changes were observed in fetal or adult sheep. Alward et al. (5) observed a decrease in RBF, a stable GFR and an increase in $\mathrm{RVR}$ in piglets exposed to combined hypercapnia $\left(\mathrm{P}_{\mathrm{a}} \mathrm{CO}_{2} 70 \mathrm{~mm}\right.$ $\mathrm{Hg})$ and hypoxemia $\left(\mathrm{P}_{\mathrm{a}} \mathrm{O}_{2} 35 \mathrm{~mm} \mathrm{Hg}\right)$. In adult animals most studies have been performed in anesthetized dogs, who frequently presented with a decrease in RBF and GFR when the $\mathrm{P}_{\mathrm{a}} \mathrm{CO}_{2}$

Received September 18, 1985; accepted April 7, 1986

Address for correspondence and reprint requests J. P. Guignard, Service de Pédiatrie, BH 11, Centre Hospitalier Universitaire Vaudois, CH-1011 Lausanne, Switzerland.

This research was supported by Grant 3.927-0.80 of the Swiss National Science Foundation. A.J.v.d.H. was a recipient of a postdoctoral fellowship of the Sophia Foundation for Medical Research.

${ }^{1}$ Presented in part at the Annual Meetings of the Swiss Society of Nephrology (Bern 1984) and of the European Society for Paediatric Nephrology (Lisboa 1985)

${ }^{2}$ Present address Department of Pediatric Nephrology, Sophia Children's Hospital, Rotterdam, The Netherlands. exceeded 70 to $80 \mathrm{~mm} \mathrm{Hg}(6-8)$. The purpose of the present study was to investigate the role of acute hypercapnia on renal function in the newborn rabbit before the end of nephrogenesis.

\section{MATERIALS AND METHODS}

Experiments were performed on 5- to 12-day-old New Zealand White rabbits $(n=45)$, with a body weight varying from 81 to $214 \mathrm{~g}$. The animals were anesthetized with $25 \mathrm{mg} / \mathrm{kg}$ sodium pentobarbital $0.5 \%$ intraperitoneally. Additional small doses of pentobarbital were administered when needed throughout the experiment. After tracheotomy the animals were artificially ventilated (Harvard 683 Rodent Ventilator, Millis, MA). The respiratory rate was kept constant at $40 / \mathrm{min}$ and tidal volume was adjusted for age and weight. Body temperature, recorded by an intraesophageal thermometer, was kept constant at $38.5^{\circ} \mathrm{C}$, using a heating table and an infrared lamp. The femoral vein and artery were catheterized with polyethylene catheters (PE 10). Bladder catheterization was performed for urine sampling. Arterial and ventilatory pressures were continuously measured, using Statham transducers and recorded on a multichannel recorder (Model 7B Polygraph, Grass Instruments, Quincy, MA). The animals were paralyzed for the duration of the experiment with tubocurarine $(25 \mu \mathrm{g} / \mathrm{kg})$, which was repeated as needed. Following surgery the animals received a priming dose of an inulin-PAH solution (100 and $1.25 \mathrm{mg} / \mathrm{kg}$, respectively). Thereafter a solution containing $50 \mathrm{~g}$ mannitol, $3 \mathrm{~g}$ inulin, $0.15 \mathrm{~g} \mathrm{PAH}$, $100 \mathrm{mmol} \mathrm{NaCl}$ and $5 \mathrm{mmol} \mathrm{KCl} /$ liter, was infused at a rate of $1 \mathrm{ml} / 100 \mathrm{~g} / \mathrm{h}$, to provide stable plasma levels of inulin $(20-40$ $\mathrm{mg} / 100 \mathrm{ml})$ and PAH $(0.2-1 \mathrm{mg} / 100 \mathrm{ml}) . \mathrm{NaHCO}_{3}$ was added to the solution in varying amounts (see below). The experiments were started 90-120 min after surgery when urinary flow and blood pressure had stabilized. During the experiment timed urinary collections of $30 \mathrm{~min}$ each were obtained and arterial blood sampling was performed at the midpoint of alternate urinary collection periods (Fig. 1). Clearances of inulin and PAH $\left(\mathrm{C}_{\mathrm{PAH}}\right)$ were calculated from standard equations and used as estimates of GFR and effective renal plasma flow. The extraction of PAH was measured in a separate group of six hypercapnic newborn animals infused with $1 \mathrm{mmol} \mathrm{NaHCO}_{3} / \mathrm{kg}$ per $\mathrm{h}\left[\mathrm{P}_{\mathrm{a}} \mathrm{CO}_{2}\right.$ $=96 \pm 6(\mathrm{SEM}) \mathrm{mm} \mathrm{Hg}$ for $60 \mathrm{~min}$ ] and compared to the value previously observed in a group of 14 normocapnic newborn rabbits $\left[\mathrm{P}_{\mathrm{a}} \mathrm{CO}_{2}=40 \pm 2(\mathrm{SEM}) \mathrm{mm} \mathrm{Hg}\right]$ studied in this laboratory (9). The extraction was $0.55 \pm 0.03$ (SEM) in the normocapnic animals and $0.56 \pm 0.09$ (SEM) in the hypercapnic animals. A value of 0.55 was subsequently used in the calculation of RBF, given by the formula $\left(\mathrm{C}_{\mathrm{PAH}} / \mathrm{E}_{\mathrm{PAH}}\right) /(1$-hematocrit $)$ and the filtration fraction $(\mathrm{FF})$ as $\mathrm{GFR} /\left(\mathrm{C}_{\mathrm{PAH}} / \mathrm{E}_{\mathrm{PAH}}\right)$. RVR was calculated as MAP/RBF. The following chemical methods were used for blood and urine analysis: inulin and PAH by the Anthron-method and the Bratton-Marshall method, respectively (Technicon Autoanalyzer, Technicon Instruments Corporation, Terrytown, NY); gas-analysis under anaerobic conditions with a blood gas-ana- 

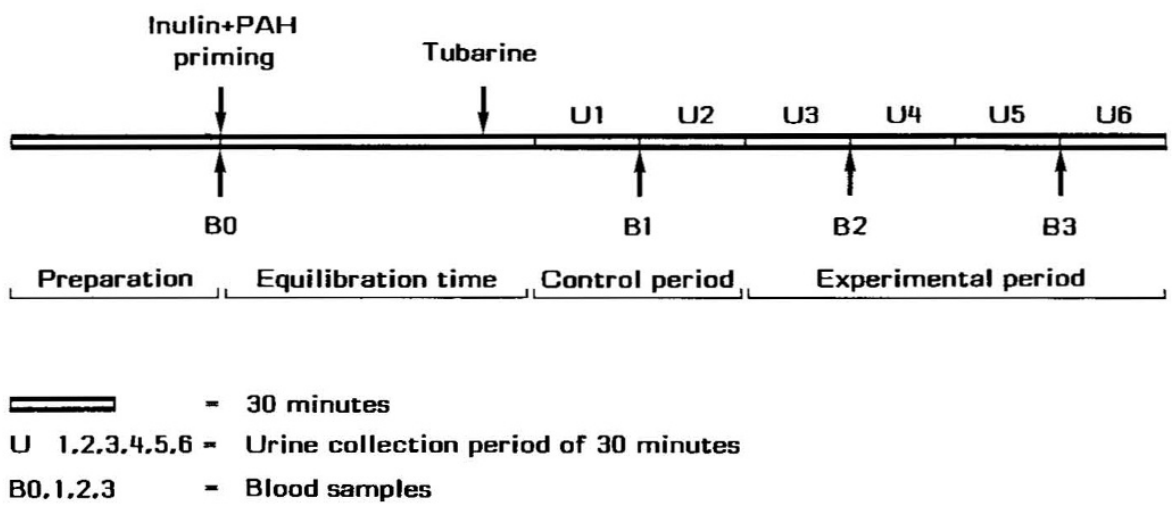

Fig. 1. Experimental protocol.

lyzer (pH/Blood-Gas Analyser 168, Corning, Halstead, Essex, England).

The following experimental protocols were used. The first two urinary collection periods always served as controls.

Group $I(n=8)$ and group II $(n=7)$. Normocapnia was maintained during 3 consecutive $\mathrm{h}$; the infusion delivered 0.5 (group I) and 1 (group II) $\mathrm{mmol} \mathrm{NaHCO}_{3} / \mathrm{kg} / \mathrm{h}$, respectively.

Group III $(n=8)$ hypercapnia. $\mathrm{A}_{2} \mathrm{CO}_{2}$ of $100 \mathrm{~mm} \mathrm{Hg}$ was obtained using a fixed gas mixture containing $13 \% \mathrm{CO}_{2}, 40 \%$ $\mathrm{O}_{2}$, and $47 \% \mathrm{~N}_{2} \cdot \mathrm{NaHCO}_{3}$ was added to the infusion to deliver $0.5 \mathrm{mmol} \mathrm{NaHCO} / \mathrm{kg} / \mathrm{h}$. Hypercapnia was introduced following the first control hour and was maintained for $2 \mathrm{~h}$.

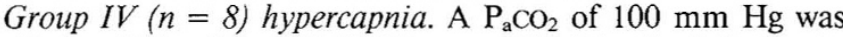
similarly obtained and $\mathrm{NaHCO}_{3}$ was added to the infusion to deliver $1 \mathrm{mmol} \mathrm{NaHCO}_{3} / \mathrm{kg} / \mathrm{h}$. The protocol was the same as used in group I.

Group $V(n=8)$ hypercapnia. $\mathrm{A}_{\mathrm{a}} \mathrm{CO}_{2}$ of $80 \mathrm{~mm} \mathrm{Hg}$ was obtained, using a fixed gas mixture containing $8 \% \mathrm{CO}_{2}, 40 \% \mathrm{O}_{2}$, and $52 \% \mathrm{~N}_{2}$. The infusion delivered $0.5 \mathrm{mmol} \mathrm{NaHCO} / \mathrm{kg} / \mathrm{h}$.

Data analysis. Because of the large interindividual and interlitter variations each animal was used as his own control. The changes between control and experimental periods have been evaluated by calculating the significance of the difference between their means and zero, using the $t$ test (10). In all cases a $p$ $<0.05$ was considered statistically significant.

\section{RESULTS}

Groups $I$ and II. Infusion of 0.5 and $1 \mathrm{mmol}$ sodium bicarbonate during 3 consecutive $\mathrm{h}$ of normocapnia did not significantly influence blood $\mathrm{pH}, \mathrm{P}_{\mathrm{a}} \mathrm{CO}_{2}$, and MAP. Except for a significant rise in urinary flow rate in group II due to the higher solute load, renal function remained essentially stable.

Effect of hypercapnia with a $\mathrm{P}_{a} \mathrm{CO}_{2}$ of $100 \mathrm{~mm} \mathrm{Hg}$ and $a$ $\mathrm{NaHCO}_{3}$ infusion rate of $0.5 \mathrm{mmol} \mathrm{NaHCO}_{3} / \mathrm{kg} / \mathrm{h}$ (group III). The $\mathrm{P}_{2} \mathrm{CO}_{2}$ was increased from 39 to $103 \mathrm{~mm} \mathrm{Hg}$ in the 1 st h of hypercapnia and to $106 \mathrm{~mm} \mathrm{Hg}$ in the $2 \mathrm{nd} \mathrm{h}$. The serum $\mathrm{pH}$ diminished abruptly from 7.48 to 7.10 during hypercapnia and remained stable for $2 \mathrm{~h}$. MAP decreased slightly, but significantly, from 33.5 to $30.5 \mathrm{~mm} \mathrm{Hg}$, and urinary flow rate from 0.057 to $0.043 \mathrm{ml} / \mathrm{min} \cdot \mathrm{kg}(p<0.05)$. There was no significant change in urinary output between the 1 st and $2 \mathrm{nd}$ h of hypercapnia. $\mathrm{C}_{\mathrm{PAH}}$ fell from 6.42 to $3.86 \mathrm{ml} / \mathrm{min} \cdot \mathrm{kg}$ within the $1 \mathrm{st} \mathrm{h}$ of hypercapnia and to $3.33 \mathrm{ml} / \mathrm{min} \cdot \mathrm{kg}$ during the $2 \mathrm{nd} \mathrm{h}$. The clearance of inulin fell from 1.66 to 1.33 within $1 \mathrm{~h}$ and to $1.22 \mathrm{ml} / \mathrm{min} \cdot \mathrm{kg}$ (Table 1) within the 2 nd $h$.

Effect of hypercapnia with a $\mathrm{P}_{a} \mathrm{CO}_{2}$ of $100 \mathrm{~mm} \mathrm{Hg}$ and $a$ $\mathrm{NaHCO}_{3}$ infusion rate of $1 \mathrm{mmol} \mathrm{NaHCO} / \mathrm{kg} / \mathrm{h}$ (group IV). The $\mathrm{NaHCO}_{3}$ infusion rate was doubled in this group to partly blunt the decrease in serum $\mathrm{pH}$ while maintaining the same $\mathrm{P}_{\mathrm{a}} \mathrm{CO}_{2}$. The increase in $\mathrm{P}_{\mathrm{a}} \mathrm{CO}_{2}$ was similar to that present in the first group, from 39 to $104 \mathrm{~mm} \mathrm{Hg}$. The decrease in serum $\mathrm{pH}$ was less pronounced, from 7.51 to 7.17. No decrease in MAP was observed and although urinary flow rate decreased from 0.064 to $0.058 \mathrm{ml} / \mathrm{kg} \cdot \mathrm{min}$, the fall was not significant. However, the decrease of $\mathrm{C}_{\mathrm{PAH}}$ was similar from 5.91 to 4.14 in the 1 st hypercapnic $\mathrm{h}$ and to $3.07 \mathrm{ml} / \mathrm{kg} \cdot \mathrm{min}$ in the 2 nd hypercapnic $\mathrm{h}$. The decrease in GFR observed during the 1 st $\mathrm{h}$ of hypercapnia was not significant from 1.56 to $1.36 \mathrm{ml} / \mathrm{kg} \cdot \mathrm{min}$, but later reached statistical significance $(p<0.05)$ (Table 1$)$.

Effect of hypercapnia with a $\mathrm{P}_{a} \mathrm{CO}_{2}$ of $80 \mathrm{~mm} \mathrm{Hg}$ and a $\mathrm{NaHCO}_{3}$ infusion rate of $0.5 \mathrm{mmol} \mathrm{NaHCO} / \mathrm{kg} / \mathrm{h}$ (group V). The $\mathrm{P}_{\mathrm{a}} \mathrm{CO}_{2}$ increased from 35 to $78 \mathrm{~mm} \mathrm{Hg}$ in the $1 \mathrm{st} \mathrm{h}$ and to $80 \mathrm{~mm} \mathrm{Hg}$ in the $2 \mathrm{nd} h$ of hypercapnia. Serum $\mathrm{pH}$ decreased from 7.51 to 7.20 and remained stable afterward. MAP remained stable throughout the experiment and the observed decrease in urinary volume was not significant. A marked decrease in $\mathrm{C}_{\mathrm{PAH}}$ from 7.45 to 5.16 during the $1 \mathrm{st} \mathrm{h}$ and to $4.43 \mathrm{ml} / \mathrm{kg} \cdot \min$ during the 2nd $\mathrm{h}$, was also observed in this group. GFR declined from 2.03 to 1.57 and to $1.64 \mathrm{ml} / \mathrm{kg} \cdot \mathrm{min}$ in the $1 \mathrm{st}$ and $2 \mathrm{nd} \mathrm{h}$, respectively (Table 1). The decrease in RBF is shown in Table 2 together with the concomitant increase in RVR. Filtration fraction increased in all hypercapnic groups.

\section{DISCUSSION}

The present study demonstrates that acute hypercapnia in the anesthetized newborn rabbit is associated with major changes in renal function. Three different experimental protocols were used in order to establish this. The significant decrease in MAP in group III could be prevented by adding $0.5 \mathrm{mmol} \mathrm{NaHCO} / \mathrm{kg} /$ $\mathrm{h}$ to the infusion in group IV. This may be due to the higher level of serum $\mathrm{pH}$ or to the expansion of extracellular volume by the hyperosmolar infusion. The effect of a fall in MAP was thus excluded in this group and was also absent in the other groups. $\mathrm{A}_{\mathrm{a}} \mathrm{CO}_{2}$ of $100 \mathrm{~mm} \mathrm{Hg}$ with a serum $\mathrm{pH}$ of $7.15-7.17$ (group IV) led to nearly the same changes as a $\mathrm{P}_{\mathrm{a}} \mathrm{CO}_{2}$ of $80 \mathrm{~mm}$ $\mathrm{Hg}$ and a serum $\mathrm{pH}$ of 7.20 (group V). Only the GFR in group V seemed to stabilize. The observed effects can be due to the hypercapnia, the acidosis, or to the combination of these factors, but remained present in all experiments thus supporting the consistency of the data. The most striking change is the decline in PAH clearance observed in all hypercapnic groups. This could reflect a true decrease in RBF or a decrease in PAH extraction in the hypercapnic animals. To exclude this second possibility, additional experiments were performed in newborn animals of the same age, undergoing hypercapnia for $60 \mathrm{~min}$. The PAH extraction values were comparable to those observed in normocapnic animals, thus demonstrating that hypercapnia does not change $\mathrm{PAH}$ extraction, and that the drop in $\mathrm{C}_{\mathrm{PAH}}$ corresponds to a true decrease in RBF. A $10 \%$ decrease in PAH extraction was observed by Anderson et al. $(11,12)$ during hypercapnic acidosis in dogs, but was apparently not found in other studies of the same group $(13,14)$, nor was any change in PAH extraction 
Table 1. Effect of hypercapnia on blood $p H, M A P$, and renal function*

\begin{tabular}{|c|c|c|c|c|c|c|c|c|c|c|c|c|c|c|c|c|c|c|c|}
\hline & & \multicolumn{3}{|c|}{$\begin{array}{c}\mathrm{P}_{\mathrm{a} C \mathrm{CO}_{2}} \\
(\mathrm{~mm} \mathrm{Hg})\end{array}$} & \multicolumn{3}{|c|}{ Blood pH } & \multicolumn{3}{|c|}{$\begin{array}{c}\text { MAP } \\
(\mathrm{mm} \mathrm{Hg})\end{array}$} & \multicolumn{3}{|c|}{$\begin{array}{c}\mathrm{V} \\
(\mathrm{ml} / \mathrm{min} \cdot \mathrm{kg})\end{array}$} & \multicolumn{3}{|c|}{$\begin{array}{c}\mathrm{C}_{\mathrm{PAH}} \\
(\mathrm{ml} / \mathrm{min} \cdot \mathrm{kg})\end{array}$} & \multicolumn{3}{|c|}{$\begin{array}{c}\mathrm{C}_{\text {inulin }} \\
(\mathrm{ml} / \mathrm{min} \cdot \mathrm{kg})\end{array}$} \\
\hline & & $\mathrm{C}$ & 1 & 2 & $\mathrm{C}$ & 1 & 2 & $\mathrm{C}$ & 1 & 2 & $\mathrm{C}$ & 1 & 2 & $\mathrm{C}$ & 1 & 2 & $\mathrm{C}$ & 1 & 2 \\
\hline 1 & Mean & 42 & 42 & 38 & 7.48 & 7.45 & 7.49 & 31.3 & 30.3 & 29.6 & 0.071 & 0.075 & 0.081 & 5.32 & 4.79 & 4.70 & 1.71 & 1.55 & 1.55 \\
\hline$n=8$ & $\begin{array}{l}\text { SEM } \\
p\end{array}$ & 2.4 & 2.0 & 1.7 & 0.03 & 0.03 & 0.02 & 1.2 & 1.4 & 1.7 & 0.008 & 0.010 & 0.015 & 0.87 & 0.48 & 0.64 & 0.26 & 0.22 & 0.27 \\
\hline II & Mean & 37 & 37 & 36 & 7.51 & 7.52 & 7.52 & 35.5 & 34.5 & 35.0 & 0.054 & 0.064 & 0.079 & 6.58 & 6.88 & 6.43 & 1.68 & 1.69 & 1.74 \\
\hline$n=7$ & $\begin{array}{l}\text { SEM } \\
p\end{array}$ & 2.3 & 1.7 & 1.6 & 0.03 & 0.02 & 0.02 & 2.0 & 2.0 & 1.8 & 0.009 & $\begin{array}{c}0.008 \\
+\end{array}$ & 0.009 & 1.32 & 1.54 & 1.65 & 0.18 & 0.23 & 0.14 \\
\hline III & $\begin{array}{l}\text { Mean } \\
\text { SEM }\end{array}$ & $\begin{array}{l}39 \\
2.4\end{array}$ & $\begin{array}{r}103 \\
1.3\end{array}$ & $\begin{array}{r}106 \\
1.8\end{array}$ & $\begin{array}{l}7.48 \\
0.01\end{array}$ & $\begin{array}{l}7.10 \\
0.01\end{array}$ & $\begin{array}{l}7.10 \\
0.01\end{array}$ & $\begin{array}{r}33.5 \\
1.0\end{array}$ & $\begin{array}{r}30.5 \\
1.3\end{array}$ & $\begin{array}{r}29.5 \\
1.3\end{array}$ & $\begin{array}{l}0.057 \\
0.007\end{array}$ & $\begin{array}{l}0.043 \\
0.005\end{array}$ & $\begin{array}{l}0.050 \\
0.009\end{array}$ & $\begin{array}{l}6.42 \\
0.67\end{array}$ & $\begin{array}{l}3.86 \\
0.45\end{array}$ & $\begin{array}{l}3.33 \\
0.61\end{array}$ & $\begin{array}{l}1.66 \\
0.14\end{array}$ & $\begin{array}{l}1.33 \\
0.14\end{array}$ & $\begin{array}{l}1.22 \\
0.24\end{array}$ \\
\hline$n=8$ & $p$ & & $\ddagger$ & $\ddagger$ & & + & $\ddagger$ & & $\dagger$ & $\dagger$ & & $\dagger$ & & & $\S$ & $\S$ & & + & \\
\hline IV & Mean & 39 & 101 & 104 & 7.51 & 7.15 & 7.17 & 32.8 & 33.9 & 34.7 & 0.064 & 0.058 & 0.060 & 5.91 & 4.14 & 3.07 & 1.56 & 1.36 & 1.29 \\
\hline & SEM & 1.7 & 1.5 & 3.2 & 0.02 & 0.01 & 0.01 & 1.2 & 1.8 & 2.0 & 0.006 & 0.005 & 0.003 & 0.39 & 0.30 & 0.34 & 0.12 & 0.07 & 0.11 \\
\hline$n=8$ & $p$ & & $\ddagger$ & $\ddagger$ & & $\ddagger$ & $\ddagger$ & & & & & & & & $\dagger$ & $\ddagger$ I & & & $\dagger$ \\
\hline V & Mean & 35 & 78 & 80 & 7.51 & 7.20 & 7.21 & 33.7 & 32.6 & 32.9 & 0.079 & 0.056 & 0.070 & 7.45 & 5.16 & 4.43 & 2.03 & 1.57 & 1.64 \\
\hline$n=8$ & $\begin{array}{l}\text { SEM } \\
p \\
\end{array}$ & 2.0 & $\begin{array}{l}1.9 \\
+ \\
\end{array}$ & $\begin{array}{l}1.8 \\
+\end{array}$ & 0.02 & $\begin{array}{c}0.02 \\
\ddagger\end{array}$ & $\begin{array}{c}0.02 \\
+ \\
\end{array}$ & 0.7 & 0.8 & 1.1 & 0.011 & 0.004 & 0.007 & 0.43 & $\begin{array}{c}0.38 \\
\S \\
\end{array}$ & $\begin{array}{c}0.48 \\
\S \\
\end{array}$ & 0.20 & $\begin{array}{c}0.14 \\
\dagger\end{array}$ & 0.19 \\
\hline
\end{tabular}

* V , urine flow rate: $C_{\text {inulin, }}$ glomerular filtration rate; $C$, control period; 1 , first period of hypercapnia; 2 , second period of hypercapnia.

$\uparrow$ Significant $v$ s control $<0.05$.

$\ddagger$ Significant vs control $<0.001$

$\S$ Significant $v s$ control $<0.01$.

$\|$ Significant $v s$ first period $<0.05$.

I Significant $v$ s first period $<0.001$.

Table 2. Values of $R B F, R V R$, and FF before and during hypercapnic acidosis*

\begin{tabular}{|c|c|c|c|c|c|c|c|c|c|c|}
\hline & & \multicolumn{3}{|c|}{$\begin{array}{c}\mathrm{RBF} \\
(\mathrm{ml} / \mathrm{min} \cdot \mathrm{kg})\end{array}$} & \multicolumn{3}{|c|}{$\begin{array}{c}\text { RVR } \\
(\mathrm{mm} \mathrm{Hg} / \mathrm{ml} / \mathrm{min} \cdot \mathrm{kg})\end{array}$} & \multicolumn{3}{|c|}{$\begin{array}{l}\text { FF } \\
(\%)\end{array}$} \\
\hline & & $\mathrm{C}$ & 1 & 2 & $\mathrm{C}$ & 1 & 2 & $\mathrm{C}$ & 1 & 2 \\
\hline \multirow[t]{2}{*}{ I } & Mean & 14.06 & 12.38 & 11.95 & 2.52 & 2.55 & 2.77 & 18.2 & 17.5 & 17.4 \\
\hline & SEM & 2.30 & 1.21 & 1.64 & 0.31 & 0.18 & 0.38 & 1.0 & 1.0 & 0.9 \\
\hline$n=8$ & $p$ & & & & & & & & & \\
\hline \multirow[t]{2}{*}{ II } & Mean & 17.14 & 17.29 & 15.92 & 2.61 & 2.49 & 2.83 & 17.2 & 16.0 & 18.4 \\
\hline & SEM & 3.36 & 3.68 & 3.93 & 0.50 & 0.44 & 0.46 & 2.7 & 2.4 & 2.4 \\
\hline$n=7$ & $p$ & & & & & & & & & \\
\hline \multirow[t]{2}{*}{ III } & Mean & 15.63 & 9.69 & 8.21 & 2.20 & 3.36 & 4.57 & 15.3 & 18.4 & 19.7 \\
\hline & SEM & 1.12 & 1.14 & 1.51 & 0.26 & 0.41 & 0.92 & 1.3 & 1.7 & 0.8 \\
\hline$n=8$ & $p$ & & $\S$ & $\S$ & & $\dagger$ & $\dagger$ & & $\dagger$ & $\S, \|$ \\
\hline \multirow[t]{2}{*}{ IV } & Mean & 15.40 & 10.63 & 7.99 & 2.17 & 3.29 & 4.70 & 14.6 & 18.3 & 23.7 \\
\hline & SEM & 1.11 & 0.75 & 0.97 & 0.14 & 0.33 & 0.55 & 0.7 & 0.9 & 1.5 \\
\hline$n=8$ & $p$ & & $\S$ & $\ddagger, \S$ & & $\dagger$ & $\S, \|$ & & $\S$ & $\ddagger{ }^{* *}$ \\
\hline \multirow[t]{2}{*}{$\mathrm{V}$} & Mean & 19.36 & 13.20 & 11.53 & 1.76 & 2.54 & 3.12 & 14.8 & 17.0 & 20.4 \\
\hline & SEM & 0.99 & 0.83 & 1.33 & 0.08 & 0.17 & 0.34 & 0.9 & 1.2 & 0.7 \\
\hline$n=8$ & $p$ & & $\ddagger$ & $\ddagger$ & & + & $\S$ & & $\dagger$ & $\ddagger$ \\
\hline
\end{tabular}

* FF, filtration fraction: $\mathrm{C}$, control period: 1 , first period of hypercapnia: 2 , second period of hypercapnia. A constant extraction factor of PAH of $55 \%$ was used for the calculation of RBF.

$\dagger$ Significant $v s$ control $<0.05$.

$\ddagger$ Significant $v s$ control $<0.001$.

$\S$ Significant $v$ f first period $<0.01$.

$\|$ Significant $v s$ control $<0.05$.

I Significant $v$ s first period $<0.01$.

** Significant $v s$ first period $<0.001$.

during hypercapnia mentioned by Norman et al. (7) and by Berns et al. (15). This is in agreement with studies using either a sine wave electromagnetic flowmeter $(6)$ or microspheres $(4,5)$ for measuring RBF.
The increase in filtration fraction suggests that the vasoconstriction induced by hypercapnia, predominates at the level of the efferent arteriole. The effects observed in our experiments are similar to the changes described in the adult dog by several 
authors (6-8). Rose et al. (14) discussed the validity of these results in dogs, arguing that the introduction of artificial ventilation and the use of pentobarbital could be responsible for the observed decrease in RBF, which they did not observe in their experiments on conscious dogs. Indeed Walker et al. (16) have clearly shown that pentobarbital can depress both RBF and GFR. However, in the protocol used by Rose, the levels of $\mathrm{P}_{\mathrm{a}} \mathrm{CO}_{2}$ were much lower than in our study, or in the studies mentioned above $(6-8)$. It should also be noted that in another study the same group did not find a decrease in RBF in similar conditions despite the use of pentobarbital, at least when MAP was stable (13). That the decrease in RBF observed in our experiments is not due either to pentobarbital or to the artificial ventilation is demonstrated by the stability of the two control groups throughout the experiment. Several mechanisms may contribute to the decrease in RBF observed during hypercapnia. A major activation of the renin-angiotensin system has been found in neonates with respiratory distress syndrome (17) as well as in adults with acute hypercapnia (18). This has been confirmed in animal experiments by Kurtz and Zehr (19). A predominant effect of angiotensin II on the efferent arteriole of the rabbit kidney has been observed by Edwards (20), which may explain the increase in filtration fraction in our experiments.

The changes in RBF observed in our experiments can thus be due to a direct stimulation of the renin-angiotensin system by hypercapnia, or to a stimulation via the renal nerves as suggested by different authors $(7,12,13,15,20)$.

AVP may be another important factor. An hyperosmolar infusion was used in our newborn rabbits. This may have stimulated AVP secretion, as has been demonstrated in the fetal sheep (21). However, the hypersecretion of AVP did certainly not influence renal hemodynamics or urinary volume in the two control groups. Hypercapnia per se also stimulates AVP secretion, as observed in the adult dog by Berns et al. (15). Thus a role for AVP in our experiments cannot be excluded.

In conclusion, acute hypercapnic acidosis in the anesthetized newborn rabbit leads to an increase in RVR, a decrease in RBF and, as a result of this, a decrease in GFR. We suggest that the renal disturbances observed in neonates with respiratory distress syndrome could be due, at least in part, to the effect of hypercapnic acidosis superimposed on the already known effects of hypoxemia.

Acknowledgments. The technical assistance of Miss Michèle Thonney and the secretarial help of Mrs. J. Jagdeep is gratefully acknowledged. The authors thank Dr. Marianne Duarte-Silva and Prof. Dr. E. Gautier for advice and criticism.

\section{REFERENCES}

1. Guignard JP, Torrado A, Mazouni S, Gautier E 1976 Renal function in respiratory distress syndrome. J Pediatr 88:845-850

2. Torrado A, Guignard JP, Prod'hom LS, Gautier E 1974 Hypoxaemia and renal function in newborns with respiratory distress syndrome (RDS). Helv Paediatr Acta 28:399-405

3. Cort R 1962 Renal function in the respiratory distress syndrome. Acta Paediatr Scand 51:313-323

4. Rosenberg AA, Koehler RC, Douglas Jones M 1984 Distribution of cardiac output in fetal and neonatal lambs with acute respiratory acidosis. Pediatr Res 18:731-735

5. Alward CT, Hook JB, Helmrath TA, Bailie MD 1978 Effects of asphyxia on renal function in the newborn piglet. Pediar Res 12:225-228

6. Bersentes TJ, Simmons DH 1967 Effects of acute acidosis on renal hemodynamics. Am J Physiol 212:633-640

7. Norman JN, MacIntyre J, Shearer JR, Craigen IM, Smith G 1970 Effect of carbon dioxide on renal blood flow. Am J Physiol 219:672-676.

8. Farber MO, Szwed JJ, Dowell AR, Strawbridge RA 1976 The acute effects of respiratory and metabolic acidosis on renal function in the dog. Clin Sci Mol Med 50:165-169

9. Vallotton M 1985 Maturation de la fonction rénale chez le lapin nouveauné-effet de l'hypoxémie. Thèse, Université de Lausanne, Switzerland

10. Snedecor G 1956 Statistical Methods Applied to Experiment in Agriculture and in Biology. Iowa State College Press, Ames, Iowa

11. Anderson RJ, Henrich WL, Gross PA, Dillingham MA 1982 Role of renal nerves. angiotensin II, and prostaglandins in the antinatriuretic response to acute hypercapnic acidosis in the dog. Circ Res 50:294-300

12. Anderson RJ, Pluss RG, Pluss WT, Bell J, Zerbe GG 1983 Effect of hypoxia and hypercapnic acidosis on renal autoregulation in the dog: role of renal nerves. Clin Sci 65:533-538

13. Anderson RJ, Rose CE, Berns AS, Erickson AL, Arnold PE 1980 Mechanism of effect of hypercapnic acidosis on renin secretion in the dog. Am J Physiol 238:F119-125

14. Rose CE, Walker BE, Erickson A, Kaiser DL, Carey RM, Anderson RJ 1982 Renal and cardiovascular responses to acute hypercapnic acidosis in conscious dogs: role of renin-angiotensin. J Cardiovasc Pharmacol 4:676-687

15. Berns AS, Anderson RJ, McDonald KM 1979 Effect of hypercapnic acidosis on renal water excretion in the dog. Kidney Int 15:116-125

16. Walker LA, Buscemi-Bergin M, Gellai M 1983 Renal hemodynamics in conscious rats: effects of anesthesia, surgery, and recovery. Am J Physiol 245:F67-74

17. Broughton Pipkin F, Smales O 1977 A study of factors affecting blood pressure and angiotensin II in newborn infants. J Pediatr 91:113-119

18. Anderson WA, Datta J, Samols E 1976 The renin angiotensin system in patients with acute respiratory insufficiency. Chest 69:309-311

19. Kurz KD, Zehr JE 1978 Mechanisms of enhanced renin secretion during $\mathrm{CO}_{2^{-}}$ retention in dogs. Am J Physiol 234:573-581

20. Edwards RM 1983 Segmental effects of norepinephrine and angiotensin II on isolated renal microvessels. Am J Physiol 244:F526-534

21. Weitzman RE, Fisher DA, Robillard J, Erenberg A, Kennedy R, Smith F 1978 Arginine vasopressin response to an osmotic stimulus in the fetal sheep. Pediatr Res 12:35-38 